\title{
O ser no gerúndio: o subjetivar-se que não cessa de acontecer
}

\author{
Marisa Schargel Maia* \\ Universidade Federal do Rio de Janeiro, Mestrado Profissional em Saúde Perinatal da Maternidade Escola. \\ Rio de Janeiro, RJ, Brasil
}

\section{Resenha de: Rozenthal, E. (2014). O ser no gerúndio: corpo e sensibilidade na psicanálise. Rio de Janeiro, RJ: Companhia de Freud.}

É, no mínimo, curioso o título do livro de Eduardo Rozenthal, O ser no gerúndio, ou seja: Sendo. Território subjetivo que é fluido e aponta para um constante devir. Se sou agora, já fui logo depois, mas fugidiamente continuo sendo em um tempo que não passa, tempo imanente.

Faz sentido pensar nas configurações subjetivas da atualidade por um tempo verbal que indica movimento. Afinal, é muito comum ouvir adolescentes ou jovens adultos que não suportam o enquadramento que o stablishment tenta lhes impor. A experimentação da vida, hoje, é mais fluida e o verbo ser no gerúndio se conjuga mais facilmente do que o verbo ser no presente. Um jovem dizia: "estou vivendo um relacionamento com alguém do meu sexo, mas não sou homossexual (estou homossexual), amanhã poderei viver outra coisa", segue sendo, mas não se fixa. O ser no gerúndio e o ideário cultural contemporâneo se imbricam de muitas maneiras. No campo do trabalho, por exemplo, o processo de construção de uma profissão sofreu mudanças radicais. No passado, esperava-se que a construção de uma carreira profissional fosse lenta e gradual, obedecendo a uma progressiva fixação da pessoa a um determinado campo; hoje, espera-se e se aprecia a capacidade de fluidez e desterritorialização em que aqueles que se deslocam (física e subjetivamente) com mais facilidade têm as melhores oportunidades.

$\mathrm{O}$ zeitgeist de um período histórico específico fomenta determinadas configurações subjetivas, e seu refugo sintomático abunda nos consultórios. É a partir desse caldo de cultura que o psicanalista, imerso em seu tempo histórico, vive sua clínica. Ao pensar sua prática, dobra-se sobre a teoria e a tenciona para responder aos desafios que a clínica lhe impõe. Aqui reside a beleza e a força da teorização psicanalítica sem a qual a Psicanálise correria o risco de se restringir ao empoeirado dos tempos idos.

Eduardo Rozenthal não recua diante dos desafios. Tal qual um cartógrafo, segue nas trilhas da metapsicologia freudiana, mas inventando novos caminhos e amarrações conceituais, afetando e sendo afetado por diversas fontes

* Autora correspondente: msmaia@centroin.com.br que o tocam desde sua prática clínica até os livros com os quais se agencia. Rozenthal sabe que, para tal intento, é preciso levar ferramentas potentes em seu embornal de caminhante, e as busca recorrendo a dois campos de pensamento: primeiro, ao campo psicanalítico, como não podia deixar de ser, Freud como base, passando por Ferenczi, Lacan, Balint, Winnicott, Leclaire e Fédida; segundo, ao campo filosófico, promovendo bons encontros entre Foucault, Deleuze, Agamben, Gil, Leibniz, entre outros. Dessa forma, amplia seu horizonte sobre a condição humana com a mediação indispensável de Daniel Stern.

Em seu caminho, o autor finca uma bandeira poderosa, destacando a importância dos encontros para os processos de subjetivação. As psicopatologias da atualidade o levam aos primórdios dos processos de constituição do psiquismo, âmbito da força pura, da angústia automática, onde o trauma é fundante e indizível. Neste contexto, o encontro da mãe com seu bebê é vital e o coloca em marcha. Se uma tartaruguinha precisa e corre para o mar ao nascer, o bebê precisa de outro que o acolha, que lance sobre ele seu investimento erótico e assim o fisgue para a vida. A dimensão alteritária transubjetiva é o marco inaugural do humano que cria um manancial de potência afetiva para todo o percurso de uma vida, a qual nos assegura um constante devir e, consequentemente, uma abertura aos processos criativos. Não se trata de produção de nenhuma obra de arte; aqui estou me referindo à criação do próprio, de si; do eu em constante negociação com o mundo; da criação de seus tons afetivos, de sua "palheta" singular constituída com as cores de seu estilo. Esta potência não está na origem, como assevera Rozenthal, ela é imanente.

Nesse contexto, o autor, ousando no campo conceitual, pede que esqueçamos as "velhas" dicotomias, já tão debatidas na psicanálise - corpo/alma, força/representação -, e propõe que se faça uma reflexão sobre o estatuto do corpo na teoria freudiana, tomando como eixo da reflexão "a alternativa entre a transcendência ou a imanência do dito corpo ao psiquismo" (p. 37). Enfatiza que é mais rico pensar os processos de subjetivação através da articulação processual entre corpo e psiquismo do que analisar o que 
aproxima ou distancia um do outro, o que já apontaria, paradoxalmente, para uma dicotomização, não só do objeto de estudo, mas da própria forma de construir a reflexão conceitual.

Na experiência psicanalítica, a potência do encontro alavanca a teoria da clínica e da metapsicologia, fazendo surgir no percurso clínico agenciamentos entre analista e analisante que não só possibilitam o manejo terapêutico, mas também instalam as condições intersubjetivas que singularizam a criação de novos universos de referência no processo psicanalítico. É importante destacar a relevância deste processo para o tratamento de pacientes difíceis, mas é igualmente importante dizer que tais processos são próprios dos modos de subjetivação que sustentam nossa vitalidade no percurso de uma vida, comparecendo sempre em qualquer processo clínico.

No entanto, como sublinha Rozenthal, a alteridade não pode se constituir como um novo patamar de transcendência, uma vez que os processos de subjetivação imanentes ocorrem em campo alteritário e se nutrem do encontro. Diz: "é da potência do encontro - mas não da alteridade, como agente distinto - que, em última análise, o processo imanente se nutre" (p. 40).

Finalizando, é preciso que tenhamos clareza de que o nosso Ser no gerúndio, o Sendo, está em constante "negociação" com o Fui, o Sou e o Serei. O Sendo, mesmo que "brinque" e "negocie" com essas outras dimensões subjetivas, tem propriedades de afeto de vitalidade, mantendo sua autonomia. O que Rozenthal traz para primeiro plano, de forma criativa e conceitualmente rigorosa, é a reflexão sobre a metapsicologia freudiana, reflexão necessária quando percebemos a gama de sintomas e adoecimentos psíquicos que ocorre quando esse bailado/entrelaçamento entre o fui, sou/sendo e serei se emperra. Essa questão já aparece na linda epígrafe do livro: "Lembra-te que afinal te resta a vida com tudo que é insolvente e provisório e de que ainda tens uma saída: entrar no acaso e amar o transitório" (Carlos Pena Filho, A solidão e sua porta).

Recebido: 21/01/2015

Aprovado: 24/04/2015 